\title{
Margem de preferência para microem- presas e empresas de pequeno porte local e regional: uma estratégia de regulação estatal desenvolvimentista
}

\author{
Preference margin for microenterprises and \\ small local and regional enterprises: a strategy \\ for state development regulatory
}

\author{
Luciano Elias Reis ${ }^{1}$ \\ Luiz Alberto Blanchet ${ }^{2}$
}

Resumo: O presente ensaio versa sobre o papel regulatório efetuado pelo Estado Brasileiro a partir das licitações públicas e dos contratos administrativos. Dentro deste contexto e concretizando o dever constitucional de propiciar um

1 Professor de Direito Administrativo do UNICURITIBA; Doutorando e Mestre em Direito Econômico pela PUC-PR; Especialista em Direito Administrativo e Processo Civil, ambos pelo Instituto de Direito Romeu Felipe Bacellar; Sócio do escritório Reis e Lippmann Advogados Associados. E-mail: luciano@rcl. adv.br.

2 Doutor e Mestre em Direito pela Universidade Federal do Paraná (1997/1991). Possui graduação em Direito pela Pontifícia Universidade Católica do Paraná (1975). Atualmente é Professor do Programa de Pós-gradução da Pontifícia Universidade Católica do Paraná (PPGD/PUCPR) e Membro Catedrático da Academia Brasileira de Direito Constitucional (ABDConst), Sócio do escritório Blanchet Advogados Associados.

E-mail: blanchet@blanchet.adv.br. 
tratamento diferenciado para as microempresas e empresas de pequeno porte, atualmente estas possuem inúmeros benefícios nos certames conforme prevê a Lei Complementar no 123/2006, o que lhes permite uma concreta vantagem em comparação com as demais pessoas jurídicas. A Lei Complementar $n^{\circ} 147 / 2014$, ao modificar parte da Lei Complementar $n^{0} 123 / 2006$, criou a margem de preferência para as microempresas e empresas de pequeno porte locais ou regionais, o que per si externou também a preocupação no fomento ao desenvolvimento socioeconômico local ou regional. Contudo, no âmbito federal, o Decreto Federal no 8538/2015 ao regulamentar a citada margem de preferência deturpou o sentido da previsão legal, incorrendo em ilegalidade quando da regulamentação.

Palavras-Chave: Licitações; Regulação; Desenvolvimento, Margem de Preferência.

Abstract: This essay deals with the regulatory role of the Brazilian State based on public tenders and administrative contracts. Within this context, and concretizing the constitutional duty to provide a differentiated treatment for micro-enterprises and small businesses, they currently have numerous benefits in the contests as provided by Complementary Law 123/2006, which allows them a concrete advantage in comparison with Other legal entities. Complementary Law No. $147 / 2014$, by modifying part of Complementary Law 123/2006, created the margin of preference for micro or small local or regional companies, 
which also expressed concern for the promotion of local socioeconomic development Or regional. However, at Federal level, Federal Decree No. $8538 / 2015$ in regulating said margin of preference misrepresented the meaning of the legal provision, incurring in illegality when the regulation.

Keywords: Biddings, Regulation; Development, Preference margin .

Sumário: 1. Introdução; 2. Uma proposta de definição de regulação; 3 . A regulação pelas licitações públicas e pelos contratos administrativos; 4 . O regime diferenciado às microempresas e empresas de pequeno porte nas licitações e nos contratos administrativos: a margem de preferência adicional; 5. Conclusão

\section{Introdução}

Desde a última década, a atuação estatal brasileira perpassa pela imperiosidade de revisitar a regulação, inclusive utilizando a contratualização administrativa como instrumento para essa. ${ }^{3}$ Não se pode mais estudar a teoria regulatória discorrendo tão somente conceitos clássicos de

3 Outros países também estão no mesmo caminho para uma reanálise da regulação estatal, conforme se desprende de obras da Espanha (PUIGPELAT, Oriol Mir. Globalización, Estado y Derecho. Las transformaciones del Derecho Administrativo. Madrid: Civitas Ediciones, 2004, p. 95-116), Portugal (MONCADA, Luís S. Cabral de. 6. ed. Direito Económico. Lisboa: Coimbra Editora, 2012, p. 425-438; GONÇALVES, Pedro Costa. Reflexões sobre o Estado Regulador e o Estado Contratante. Coimbra: Coimbra Editora, 2013), França (CHEVALLIER, Jacques. O Estado Pós-Moderno. Trad. Marçal Justen Filho. Belo Horizonte: Fórum, 2009, p. 59-80) e México (VILLANUEVA, Luis F. Aguiar. Gobernanza y gestión pública. México: FCE, 2006, p. 137-236). 
Direito Administrativo, principalmente o serviço público e o poder de polícia, já que a redução do Estado no exercício da atividade estatal como agente econômico ensejou a obrigatoriedade de se construir uma "teoria da regulação estatal em face da ordem econômica." 4

Jacques Chevallier defende que a regulação acarreta uma nova concepção do papel do Estado na economia, advogando favoravelmente ao seu papel de árbitro no processo econômico, até porque, segundo o autor, "falar da função regulatória do Estado pressupõe que o sistema econômico não possa atingir por si próprio o equilíbrio, que ela tenha necessidade da mediação do Estado para o alcançar." ${ }^{5}$

Neste prumo, o uso dos contratos e dos convênios administrativos precisa ser repensado sobre a sua atual pragmaticidade (sob o viés da necessidade $x$ utilidade), levando em consideração o impacto socioeconômico de tais avenças diante do mercado e da sociedade, razão pela qual servem como meios para a implantação, adaptação mercadológica e persuasão de políticas regulatórias estatais.

Especificamente no Brasil, desde a publicação da Lei Complementar $n^{0} 123$ /2006, verificou-se a inserção no ordenamento jurídico de uma série de medidas estratégicas na economia por meio das licitações e dos contratos administrativos, motivo que enseja a indispensabilidade de analisar a definição de regulação, o regime diferenciado para as microempresas e empresas de pequeno porte prescrito, para então criticar a regulamentação federal (Decreto Federal n ${ }^{\circ}$

4 MARQUES NETO, Floriano Azevedo. Limites à abrangência e à intensidade da regulação estatal. Revista Eletrônica de Direito Administrativo Econômico, Salvador, Instituto de Direito Público da Bahia, n. 04, nov/dez 2005, jan. 2006. Disponível na internet: http://www.direitodoestado.com. br.> Acesso em 17., jul. 2014, p. 03.

5 CHEVAlLIER, Jacques. O Estado Pós-Moderno. Trad. Marçal Justen Filho. Belo Horizonte: Fórum, 2009, p. 72. 
$8.250 / 15)$ sobre a margem de preferência de dez por cento para aquelas pequenas empresas locais ou regionais.

\section{Uma proposta de definição de regulação}

A regulação se expressa pela intervenção indireta do Estado no domínio econômico. Para Marçal Justen Fiho, "revela a concepção de que a solução política mais adequada para obter os fins buscados consiste não no exercício direto e imediato pelo Estado de todas as atividades de interesse público." 6 Floriano de Azevedo Marques Neto define-a como toda "atividade estatal sobre o domínio econômico que não envolva a assunção direta da exploração de atividade econômica (em sentido amplo)." " Sob um enfoque de conformação do setor privado, Roberto Correia da Silva Gomes Caldas e Thiago Penido Martins delimitam-na como atividade estatal que visa a conformar o setor privado aos interesses públicos e compreendem todo tipo de norma jurídica e controle administrativo direcionado ao encontro da máxima eficiência alocativa e produtiva setoriais, tanto de forma ativa como passiva preventiva ou repressiva. ${ }^{8}$ Paulo Roberto Ferreira Motta, por sua vez, a caracteriza como "processo administrativo encetado pela Administração Pública, mediante a observância do regime jurídico de Direito

6 JUSTEN FILHO, Marçal. Curso de direito administrativo. 8. Ed. Belo Horizonte: Fórum, 2012, p. 639.

7 MARQUES NETO, Floriano Azevedo. Limites à abrangência e à intensidade da regulação estatal. Revista Eletrônica de Direito Administrativo Econômico, Salvador, Instituto de Direito Público da Bahia, n. 04, nov/dez 2005, jan. 2006. Disponível na internet: http://www.direitodoestado.com. br.> Acesso em 17., jul. 2014, p. 03.

8 CALDAS, Roberto Correia da Silva Gomes; MARTINS, Thiago Penido. Princípios do Equador e Governança Regulatória nas contratações públicas sustentáveis: implicações nas desapropriações. Revista Brasileira de Estudos Políticos, Belo Horizonte, n. 112, p. 183-229, jan.jun. 2016, p. 196. 
Público, de limitação (mínima, média ou máxima, conforme a opção ideológica do legislador) à liberdade e à propriedade, visando dar funcionalidade e racionalidade ao mercado." 9

A partir das posições dos juristas ora transcritos, é necessário ponderar algumas das características conceituais para encontrar uma definição de regulação. ${ }^{10}$

Pode-se cingi-la a uma mera atuação estatal ou é necessário um processo administrativo? Não obstante entendimento diverso, compreende-se que o mais adequado é estudar a regulação como conseqüência de um processo administrativo dialógico com transparência e participação popular, sempre que possível. Afirma-se "sempre que possível", visto que determinadas medidas regulatórias poderão precisar de sigilo (mínimo, médio ou máximo) estatal por questões de segurança nacional, conforme autorizado pelo artigo 5 , XXXIII, da Constituição da República Federativa do Brasil, ou até para preservação de direitos fundamentais. Nesta linha de raciocínio, regulação é a atuação estatal, decorrente de processo administrativo, que interfira na atividade econômica.

A processualidade evita atuações regulatórias arbitrárias, não pensadas, sigilosas e cooptadas por determinados atores do mercado, já que gerará a imperiosidade de planejamento, preparação material em cadernos processuais ad-

9 MOTTA, Paulo Roberto Ferreira. Regulação e universalização dos serviços públicos. Belo Horizonte: Fórum, 2009. p. 69.

10 ".Vale dizer: não há um conceito verdadeiro ou falso. Portanto, deve-se procurar adotar um que seja o mais possível útil para os fins a que se propõe o estudioso." (MELLO, Celso Antônio Bandeira de. Curso de Direito Administrativo. 25. ed. São Paulo: Malheiros, 2008, p. 374). Sobre a utilidade das classificações, vide: CARRIÓ, Genaro. Notas sobre Derecho y Lenguaje. 4. ed. Buenos Aires: Abeledo-Perrot, 1973, p. 72; CARNELUTTI, Francesco. Metodologia do Direito. Trad. Dr. Frederico Paschoal. 3. ed. Campinas: Bookseller, 2005, p. 57-58; LARENZ, Karl. Metodologia da Ciência do Direito. Fundação Calouste Gulbenkian, p. 586-587. 
ministrativos, participação popular, motivação, publicidade, prudência regulatória, análise de impacto regulatório, etc. Antes que se pressuponha que no Brasil o amparo normativo para a regulação é inadequado como um mito ricocheteado em senso comum não justificado, anui-se com a posição de Diogo Figueiredo Moreira Neto de que o suposto déficit democrático na regulação brasileira não está no sistema em si (defeitos intrínsecos), mas sim "por defeitos procedimentais atinentes à condução dos processos" e "por defeitos pessoais dos que neles estejam envolvidos em posição de responsabilidade". ${ }^{11}$

Para complementar o uso dos signos na definição mencionada linhas acima, Eros Roberto Grau diferencia as expressões "intervenção" e "atuação estatal", intervenção "conota atuação estatal no campo da atividade econômica em sentido estrito" e a atuação é "ação do Estado no campo da atividade econômica em sentido amplo". ${ }^{12}$ Já Luiz Alberto Blanchet, critica o uso do termo "intervenção", pois, a rigor, ele é mais apropriado nos casos de intervenção em concessões e de intervenção da União em Estado ou Distrito Federal ou intervenção de Estado em Município. ${ }^{13}$ Para Célia Cunha Mello, "qualquer ação estatal que repercuta na sociedade, criando, modificando ou extinguindo direitos e situações, pode ser concebida como uma forma de interferência do Estado", por isso a autora defende que interferência estatal é

11 MOREIRA NETO, Diogo Figueiredo. A regulação sob a perspectiva da nova hermenêutica. Revista Eletrônica de Direito Administrativo Econômico (REDAE), Salvador, Instituto Brasileiro de Direito Público, $\mathrm{n}^{\mathrm{o}}$ 12, novembro/dezembro/janeiro, 2008. Disponível na internet: http://www. direitodoestado.com.br.> Acesso em 30, abril. 2016, p. 12.

12 GRAU, Eros Roberto. A ordem econômica na Constituição de 1988. 15. Ed. São Paulo: Malheiros, 2012, p. 141-142.

13 BLANCHET, Luiz Alberto. Curso de Direito Administrativo. 5. ed. Curitiba: Juruá, 2007, p. 185 
gênero, compreendendo as espécies interferência em sentido estrito, cuja área de incidência é a vida privada, e intervenção, cuja área de incidência é a ordem econômica. ${ }^{14}$

Atinente ao conteúdo da regulação, Marçal Justen Filho considera que esta é uma "opção preferencial do Estado pela intervenção indireta, puramente normativa", sendo que o autor enfatiza a natureza exclusivamente normativa, a qual é a adoção de normas e outros atos estatais despidos de recursos estatais a serem aplicados para a concretização de alguma atividade no domínio econômico-social. ${ }^{15}$ Por sua vez, o caráter normativo da atuação estatal não se resume tão somente a expedição de normas gerais e abstratas, mas também a atos individuais concretos, sejam decorrentes de espécies de atos administrativos (resoluções, instruções normativas, dentre outras) ou de atos decisórios.

Egon Bockmann pontua que toda regulação é "interventiva lato sensu (pois envolve a intromissão através de normas que disciplinam o comportamento de terceiros), apesar de nem toda intervenção ser regulatória (pois a intervenção pode dar-se diretamente, através do exercício in concreto da atividade econômica)." 16 Com outro ponto de vista, Luís Cabral de Moncada defende que a regulação tem pontos comuns com a intervenção indireta, mas distingue-se dela por razões essencialmente teleológicas e funcionais, alertando em sua concepção que o conceito de intervenção

14 MELlO, Célia Cunha. O fomento da Administração Pública. Belo Horizonte: Del Rey, 2003, p. 01-02.

15 JUSTEN FILHO, Marçal. Curso de direito administrativo. 8. Ed. Belo Horizonte: Fórum, 2012, p. 638-639.

16 MOREIRA, Egon Bockmann. O Direito Administrativo Contemporâneo e Intervenção do Estado na Ordem Econômica. Revista Eletrônica de Direito Administrativo Econômico, Salvador, Instituto de Direito Público da Bahia, $\mathrm{n}^{\mathrm{o}}$ 01, fevereiro,2005. Disponível na internet: http://www.direitodoestado. com.br.> Acesso em 29. abril. 2016, p. 04. 
direta e indireta do Estado não coincidem para o Direito Administrativo e para o Direito Econômico. ${ }^{17}$ Para o jurista português, economicamente, de fato a regulação é o controle estatal sobre a atividade econômica privada e pública e visa corrigir as deficiências do mercado, sendo que tais características não são encontradas na intervenção indireta, a qual não pressupõe o mercado como modo de ser da decisão econômica e que pode ser pautada por outros propósitos, bem como realizada por entidades estatais ou paraestatais. ${ }^{18}$ Moncada ainda destaca que a intervenção indireta é sempre um instrumento de política econômica, mas a regulação é um meio de corrigir o mercado. ${ }^{19}$

Quanto ao escopo da regulação, este sempre será para consertar possíveis desvios, bem como para evitar a perduração de condutas incompatíveis com a racionalidade, harmonia e funcionalidade no mercado. Marçal Justen Filho descreve que o Estado regulador desempenha material e diretamente algumas atividades essenciais, concentrando esforços para produzir um conjunto de normas e decisões influenciadores do funcionamento das instituições estatais e não estatais. ${ }^{20}$ Paulo Motta analisa a finalidade de acordo

17 No Direito Administrativo "a intervenção é indirecta se a entidade é independente", já no Direito Econômico "a intervenção indirecta se o Estado (por si ou por interposta pessoa) não é o titular efectivo da exploração econômica." Posteriormente, continua "a intervenção (indirecta) do Estado limita-se a condicionar, a partir de fora, a actividade econômica, sem que assuma a posição de sujeito econômico activo. É o caso da criação de infraestruturas, da polícia econômica e do fomento." (MONCADA, Luís S. Cabral de. 6. ed. Direito Económico. Lisboa: Coimbra Editora, 2012, p. 48-50).

18 MONCADA, Luís S. Cabral de. 6. ed. Direito Económico. Lisboa: Coimbra Editora, 2012, p. 55.

19 MONCADA, Luís S. Cabral de. 6. ed. Direito Económico. Lisboa: Coimbra Editora, 2012, p. 55.

20 JUSTEN FILHO, Marçal. Curso de direito administrativo. 8. Ed. Belo Horizonte: Fórum, 2012, p. 639. 
com o regime jurídico, mais precisamente dizendo que quando focada à atividade privada estatui um regime de sujeição geral e impõe deveres aos agentes do mercado, por outro lado quando aos serviços públicos configura um regime de sujeição especial e gera obrigações aos prestadores e cidadãos-usuários. ${ }^{21}$

Insta consignar que a regulação vincula uma noção de sistema econômico como um todo ou no mínimo de um subsistema econômico (em casos de regulação setorial), nos quais fiquem dilucidados os valores justificadores da incidência regulatória e quais são os bens e valores a serem protegidos. ${ }^{22}$ Gaspar Ariño Ortiz enaltece o objetivo único e exclusivo da política regulatória, qual seja, "melhores condições possíveis de segurança, qualidade e preços; com a maior eficiência que o estado da arte permita, tanto para hoje como para amanhã." ${ }^{23}$ A té porque, no plano democrático constitucionalizado qualquer política pública é uma ação governamental exigida pelo seu titular- o povo. ${ }^{24}$

21 MOTTA, Paulo Roberto Ferreira. Regulação e universalização dos serviços públicos. Belo Horizonte: Fórum, 2009. p. 69.

22 MARQUES NETO, Floriano Azevedo. Limites à abrangência e à intensidade da regulação estatal. Revista Eletrônica de Direito Administrativo Econômico, Salvador, Instituto de Direito Público da Bahia, n. 04, nov/dez 2005, jan. 2006. Disponível na internet: http://www.direitodoestado.com.br.> Acesso em 17., jul. 2014, p. 04. A título ilustrativo, recomenda-se a leitura do artigo de Maurin Almeida Falcão em que traça o diálogo contínuo existente entre o Mercado e o Estado para a demarcação da economia política a partir da obra de Gilpin no mundo contemporâneo, discorrendo inclusive sobre quem seria o legítimo autor do poder político. (FALCÃO, Maurin Almeida. O Estado, o mercado e as transformações econômicas, políticas e sociais como determinantes de uma economia política do tributo. Revista Brasileira de Estudos Políticos, Belo Horizonte, n. 104, p. 263-289, jan.jun. 2012)

23 ORTIZ, Gaspar Ariño. Sucessos e Fracassos da Regulação. Revista Eletrônica de Direito Administrativo Econômico, Salvador, Instituto de Direito Público da Bahia, no. 3, ago-set-out, 2005. Disponível na Internet: <http://www.direitodoestado.com.br>. Acesso em: 20 de abril de 2016, p. 09.

24 COELHO, Saulo de Oliveira Pinto; ASSIS, Aline Neves de. Um 
Pelas considerações retro e supra, regulação é a atuação estatal, decorrente de processo administrativo, que interfira na atividade econômica visando à correção de anacronismos e à tutela preventiva de condutas incompatíveis pelos agentes com racionalidade, proporcionalidade, harmonia e funcionalidade no mercado.

\section{A regulação pelas licitações públicas e pelos con- tratos administrativos}

Inconteste a importância da função regulatória do Estado, por isso discorrer-se-á sobre uma ferramenta utilizada para induzir a missão e a "mão" regulatória do Estado para a implantação e a proteção dos fins colimados constitucionalmente: a contratualização administrativa.

Segundo Jacques Chevallier, o procedimento contratual nas sociedades contemporâneas deflui um grande crescimento a ponto de aparecer como emblemático na pós-modernidade. De acordo com o autor, o fortalecimento do contrato é acompanhando pari passu da quebra, de um lado, de uma concepção tradicionalista e autoritária diante das fronteiras entre contrato e ato unilateral; de outro, pelo aparecimento de procedimentos mais flexíveis e informais de cooperação e de regulação sob variadas denominações, razão pela qual a contratualização não ficará adstrita ao domínio econômico, mas também a outras áreas de suma importância para a intervenção estatal como ação social, meio ambiente, cultura, etc.. ${ }^{25}$

constitucionalismo do espetáculo? Espetacularização das políticas públicas e ineficiência do controle jurídico-constitucional. Revista Brasileira de Estudos Políticos, Belo Horizonte, n. 115, p. 541-584, jul.dez. 2017, p. 545.

25 CHEVALLIER, Jacques. O Estado Pós-Moderno. Trad. Marçal Justen Filho. Belo Horizonte: Fórum, 2009, p. 161-162. 
Neste sentido, Gustavo Justino de Oliveira também sinaliza que a nova contratualização administrativa é desenvolvida em bases negociais mais amplas se comparadas aos modelos contratuais tradicionais, direcionando-se "(i) para uma maior paridade entre Administração e particular e (ii) uma reforçada interdependência entre as prestações a cargo de ambas as partes" ${ }^{26}$ Consequentemente, é inegável dizer que o maior diálogo e a abertura para consenso evitam condutas arbitrárias ou inapropriadas, as quais por vezes tornam inviáveis ou sacrificantes uma parceria ou um contrato administrativo. Segundo Cristiana Fortini, atualmente vive-se a época do Direito Administrativo Consensual em que os ajustes com o setor privado são indispensáveis, não podendo continuar o raciocínio do Estado atuando somente por atos administrativos unilaterais. ${ }^{27}$

Sobre esta mudança de parâmetro e a maior consensualização da Administração Pública em seus contratos, Odete Medauar explica que a sua expansão gerou locuções como "governo por contratos", "direito administrativo pactualista", "direito administrativo cooperativo", "administração por acordos", "contratualização das políticas públicas". ${ }^{28}$ Na mesma ótica, Pedro Gonçalves propugna a importância

26 OLIVEIRA, Gustavo Justino de. A arbitragem e as parcerias públicosprivadas. In. SUNDFELD, Carlos Ari. (Org) Parcerias Público-Privadas. São Paulo: Malheiros, 2005, p. 567-606.

27 FORTINI, Cristiana. Contratos administrativos: franquia, concessão, permissão e PPP. 2. Ed. São Paulo: Atlas, 2009, p. 04,

28 MEDAUAR, Odete. Direito administrativo em evolução. 2. ed. São Paulo: Revista dos Tribunais, 2003, p. 212-213. A Administração consensual ou concertada não pode ser visualizada como um desprestígio ou aniquilamento do ato administrativo, como aponta Almiro Couto e Silva em precioso estudo. (SILVA, Almiro do Couto e. Notas sobre o conceito de ato administrativo. In: SOUTO, Marcos Juruena Villela e OSÓRIO, Fábio Medina (Coords.). Direito administrativo - Estudos em homenagem a Diogo Figueiredo Moreira Neto. Rio de Janeiro: Lumen Juris, 2006, p. 271-292, p. 291). Roberto Caldas e Thiago Martins ressaltam a denominação "processualização do 
da contratualização em sentido lato. ${ }^{29}$ Vivian Lima López Valle relaciona a nova contratualização com o incremento qualitativo e quantitativo de modo a possibilitar uma maior realização de serviços públicos, mais eficiente, e, como conseqüência, a materialização dos direitos fundamentais." ${ }^{30}$ Além do argumento do consenso para o uso da licitação para a regulação, deve-se também recorrer ao fundamento econômico, qual seja, em países em desenvolvimento as compras governamentais representam um movimento de

contrato". (CALDAS, Roberto Correia da Silva Gomes; MARTINS, Thiago Penido. Princípios do Equador e Governança Regulatória nas contratações públicas sustentáveis: implicações nas desapropriações. Revista Brasileira de Estudos Políticos, Belo Horizonte, n. 112, p. 183-229, jan.jun. 2016, p. 203).

29 "No início de um importante texto sobre a contratação pública, diz Jody Freeman que o moderno Estado administrativo se apresenta como um 'contractingstate', isto é, um Estado que interiorizou a 'cultura do contrato' como um instrumento ao serviço de realização dos seus fins institucionais. Isso assume particular notoriedade perante a importância que o contrato adquiriu no domínio do estabelecimento de formas de cooperação e de colaboração entre Estado e actores privados na gestão de serviços públicos e na execução de funções públicas. Mas o mesmo deve ainda dizer-se acerca dos chamados 'contratos regulatórios", que, em alguns sectores, tendem a substituir as tradicionais regulações unilaterais e autoritárias por uma ideia de 'contractualgovernance'. Embora se apresente com um espectro mais alargado, a contratação pública detém actualmente um relevo decisivo na reconfiguração do papel do Estado e no estabelecimento de pontes de cooperação com as entidades privadas. Neste sentido, o contrato representa um instrumento fundamental ao serviço das medidas de privatização no domínio da execução de tarefas públicas. Além dos clássicos contratos de concessão de obras e serviços públicos, o Estado recorre a outros modelos de contracting out e de outsourcing, por via dos quais confia a entidades privadas a gestão de missões públicas ou a realização de trabalhos essenciais para o desempenho das tarefas públicas pelo próprio Estado." (GONÇALVES, Pedro Antonio Pimenta da. Entidades privadas com poderes públicos: o exercício de poderes públicos de autoridade por entidades privadas com funções administrativas. Coimbra: Edições Almedina, 2008, p. 330-331). No Brasil, Fernando Dias Menezes de Almeida descreve a evolução do contrato administrativo e sua nova postura teórica (ALMEIDA, Fernando Dias Menezes. Contrato administrativo. São Paulo: QuartierLatin, 2012).

30 VALLE, Vivian Lima López. Serviço público, desenvolvimento econômico e a 
10 a 15\% do Produto Interno Bruto. ${ }^{31}$ Especificamente no Brasil, o Governo movimenta, com a aquisição de compras e contratações de serviços, cerca de $15 \%$ do seu Produto Interno Bruto - PIB. ${ }^{32}$

Diante destas breves colocações, não se pode dissociar a regulação estatal via licitação e contrato administrativo da intervenção do Estado no campo da atividade econômica em sentido estrito. Para tanto, aproveita-se a classificação de Eros Roberto Grau que diferencia esta em três modalidades: (i) intervenção por absorção ou participação ${ }^{33}$ quando o Estado intervém diretamente no domínio econômico, mais precisamente na atividade econômica em sentido estrito como agente (sujeito) econômico; ${ }^{34}$

nova contratualização da Administração Pública: o desafio na satisfação dos direitos fundamentais. In: BACELLAR FILHO, Romeu Felipe; GABARDO, Emerson; HACHEM, Daniel Wunder (Coord.). Globalização, Direitos Fundamentais e Direito Administrativo: novas perspectivas para o desenvolvimento econômico e socioambiental. Belo Horizonte: Fórum, 2011, p. 273-284, p. 282.

31 Fato reconhecido pela Organização Mundial do Comércio - OMC - em seu site: "La contratación pública representa en promedio el 10-15\% del PIB de una economía. Constituye un mercado significativo y un aspecto importante del comercio internacional. La labor de la OMC en materia de contratación pública tiene por objeto promover la transparencia, la integridad y la competencia en este mercado." (https://www.wto.org/spanish/tratop_s/ gproc_s/gproc_s.htm)

32 BRASIL, Ministério do Meio Ambiente. Licitação sustentável. Disponível em: <http://www.mma.gov.br/responsabilidade-socioambiental/a3p/eixostematicos/item/526\&gt>. Acesso em: 30 de mar. de 2015.

33 Intervenção na economia.

34 A absorção ocorre quando o Estado "assume integralmente o controle dos meios de produção e/ou troca em determinado setor da atividade econômica em sentido estrito; atua em regime de monopólio"; já a participação "o Estado assume o controle de parcela dos meios de produção e/ou troca em determinado setor da atividade econômica em sentido estrito; atua em regime de competição com empresas privadas que permanecem a exercitar suas atividades nesse mesmo setor." (GRAU, Eros Roberto. A ordem econômica na Constituição de 1988. 15. Ed. São Paulo: Malheiros, 2012, p. 143). 
(ii) intervenção por direção, ${ }^{35}$ “o Estado exerce pressão sobre a economia, estabelecendo mecanismos e normas de comportamento compulsório para os sujeitos da atividade econômica em sentido estrito"; e (iii) intervenção por indução, ${ }^{36}$ "o Estado manipula os instrumentos de intervenção em consonância e na conformidade das leis que regem o funcionamento dos mercados." ${ }^{37}$

Neste ensaio, pretende-se examinar a intervenção do Estado sobre o domínio econômico por intermédio da direção e da indução quando se utiliza a regulação via licitações e contratos administrativos para o fomento e fortalecimento das microempresas e empresas de pequeno porte. A contratação administrativa é considerada um importante objeto de regulação, pois envolve dois aspectos, segundo Pedro Costa Gonçalves: (i) a regulação normativa ou regulamentação dos procedimentos de contratação; e (ii) a regulação jurídica dos operadores econômicos que participam dos certames e integram o mercado dos licitantes. ${ }^{38}$

Quanto à constitucionalidade da regulação estatal pela contratualização administrativa a partir da Constituição da República Federativa de 1988, alvitra-se do comando normativo do artigo 174 da Lei Maior ao prescrever que o Estado, como agente normativo e regulador da atividade econômica, exerce, na forma da lei, as funções de fiscalização, incentivo e planejamento, sendo que este será determinante para o setor público e indicativo para o setor privado. Logo, o Estado deverá (e não poderá) atuar na fiscalização, planejamento e incentivo. ${ }^{39}$

35 Intervenção sobre a economia.

36 Intervenção sobre a economia.

37 GRAU, Eros Roberto. A ordem econômica na Constituição de 1988. 15. Ed. São Paulo: Malheiros, 2012, p. 143.

38 GONÇALVES, Pedro Costa. Reflexões sobre o Estado Regulador e o Estado Contratante. Coimbra: Coimbra Editora, 2013, p. 23.

39 "Mais do que simples instrumento de governo, a nossa Constituição enuncia 
Segundo Eros Roberto Grau, as normas de intervenção por indução estipulam "preceitos que, embora prescritivos (deônticos), não são dotados da mesma carga de cogência que afeta as normas de intervenção por direção". A norma de intervenção por indução confere ao destinatário a alternativa de aderir ou não à prescrição nela veiculada. Caso haja a sua adesão, resultará em benefícios usufruídos pelo aderente. Diferentemente, as normas de intervenção por direção impõem comportamentos por intermédio da cogência das normas. ${ }^{40}$

Atinente à ação estatal na intervenção por indução, salienta-se que o intuito do Estado é justamente que o aderente da medida estatal possa beneficiar-se ante os demais no mercado. $\mathrm{O}$ benefício exsurge como um prêmio àquele que realiza a conduta - seja positiva ou negativa - incitada pelo Estado. ${ }^{41} \mathrm{O}$ enaltecimento à atividade administrativa de fomento tem aparecido como um dos aspectos mais comentados da reforma estatal das últimas décadas. Sobre o assunto, Diogo Figueiredo Moreira Neto qualifica que se trata de um "direcionamento não coercitivo do Estado à sociedade, em estímulo das atividades privadas de interesse público. É uma atividade que se sistematiza e ganha consistência acoplada ao planejamento dispositivo." Por esta relevância, o autor infere que é "inegável que o fomento público, conduzido com liberdade de opção, tem elevado alcance pedagógico e integrador, podendo ser considerado, para um futuro

diretrizes, programas e fins a serem realizados pelo Estado e pela sociedade. Postula um plano de ação global normativo para o Estado e para a sociedade, informado pelos preceitos veiculados pelos seus arts. $1^{\circ}, 3^{\circ}$ e 170." (Supremo Tribunal Federal, ADI 1.950, Rel. Min. Eros Grau, julgamento em 3-11-2005, Plenário, DJ de 2-6-2006).

40 GRAU, Eros Roberto. A ordem econômica na Constituição de 1988. 15. Ed. São Paulo: Malheiros, 2012, p. 144-145.

41 GRAU, Eros Roberto. A ordem econômica na Constituição de 1988. 15. Ed. São Paulo: Malheiros, 2012, p. 145. 
ainda longínquo, a atividade mais importante e mais nobre do Estado." 42

Carlos Ari Sundfeld endossa tal relevância ao sustentar a necessidade de reconstrução da teoria da ação administrativa, a qual passa por três grandes setores, quais sejam: a administração de gestão, a administração fomentadora e a administração ordenadora. Advoga explicitamente favorável à administração fomentadora como impreterível para uma nova concepção e análise da teoria da ação administrativa, sendo que ela deverá ser compreendida como "a função de induzir, mediante estímulos e incentivos - prescindindo, portanto, de instrumentos imperativos, cogentes - os particulares a adotarem certos comportamentos." ${ }^{43}$ Ao seu lado,

42 MOREIRA NETO, Diogo Figueiredo. Mutações do Direito Administrativo. 3. ed. Rio de Janeiro: Renovar, 2007, p. 45. Silvio Luis Ferreira da Rocha define a atividade de fomento de maneira descritiva e excludente, a partir da exposição de que a Administração poderá alcançar a satisfação das necessidades coletivas a partir de sua atuação de modo direto e imediato ou de modo indireto e mediato quando as atividades são prestadas pelos particulares, as quais foram incentivadas pela Administração, e servem para alcançar as necessidades coletivas. (ROCHA, Silvio Luis Ferreira da. Terceiro Setor. 2. ed. São Paulo: Malheiros, 2006, p. 23). Ecoando a mesma finalidade, porém pontuando que poderá alcançar os estabelecimentos particulares, Roberto Dromi define o fomento administrativo como uma "acción dirigida a proteger o promover las actividades y establecimientos de los particulares, que satisfagan necesidades públicas o que se estimen de utilidad general." $\mathrm{O}$ autor argentino posiciona-se ainda que a ideia predominante do fomento é que versa sobre uma atividade persuasiva ou de estímulo, sendo que a sua finalidade será obtida com o convencimento para que se faça algo ou se omita. (DROMI, Roberto. Derecho Administrativo. 10. ed. Buenos Aires: Ciudad Argentina, 2004, p. 1027).

43 SUNDFELD, Carlos Ari. Direito Administrativo Ordenador. São Paulo: Malheiros, 2003, p. 16. Em sentido análogo, Célia Cunha conceitua a administração fomentadora "como um complexo de atividades concretas e indiretas que o Estado desempenha despido do poder de autoridade, cujo labor se limita a promover e/ou incentivar atividades e regiões, visando melhorar os níveis de vida da sociedade." (MELLO, Célia Cunha. Op. cit., p. 38). Nos mesmos termos, vide GARCÍA, Jorge Sarmiento. Derecho publico. 2. ed. Buenos Aires: Ediciones Ciudad Argentina, 1998, p. 647. 
José Roberto Pimenta Oliveira explana que para o cumprimento dos objetivos constitucionais inerentes à estruturação do Estado Social e Democrático de Direito, desenhado pela Constituição, não há como a função administrativa restringir-se, na atualidade, ao campo ordenador e sancionatório. ${ }^{4}$

No tocante à regulação estatal a partir da licitação e do contrato administrativo, tal situação pode ser visualizada por meio de algumas normas editadas nos últimos quinze anos, as quais têm promovido ou induzido a intervenção estatal. Luciano Ferraz enfoca inclusive que as medidas de regulação não precisam ser necessariamente via legislativa, mas também há a plena factibilidade de ocorrer a regulação por meio de medidas administrativas, sendo que o seu uso "atenderá basicamente a duas finalidades: a) garantia de competição no mercado, estímulo, portanto à concorrência legal; b) garantia de qualidade nas contratações da administração pública." 45

Das aludidas normas jurídicas, ${ }^{46}$ chama-se atenção para a Lei no 12.349/2010 que trouxe algumas inovações na Lei Brasileira de Licitações e Contratos Administrativos

44 Postulou-se da Administração uma crescente e cada vez mais complexa intervenção estatal no domínio social e econômico, formalizada, pela ordem jurídica, com a positivação de dever de prestar serviços públicos nos diversos campos em que o interesse da coletividade mandava uma presença ativa da atividade administrativa, considerados como atividades materiais vinculadas à existência da própria sociedade, passíveis de fruição direta pelos administrados, fornecidos pela Administração, sob regime de direito público. (OLIVEIRA, José Roberto Pimenta. Os princípios da razoabilidade e da proporcionalidade no Direito Administrativo Brasileiro. São Paulo: Malheiros, 2006, p. 514-515).

45 FERRAZ, Luciano. Função regulatória da licitação. Revista Eletrônica de Direito Administrativo Econômico, Salvador, Instituto de Direito Público da Bahia, n. 19, ago.set.out., 2009. Disponível na internet: http://www. direitodoestado.com.br.> Acesso em 12. jul. 2014, p. 13.

46 Tratar-se-á sobre o regime diferenciado para microempresa e empresa de pequeno porte no próximo tópico. 
(Lei n. 8.666/1993), dentre elas, a prescrição normativa da finalidade da "promoção do desenvolvimento nacional sustentável” (artigo 30 , caput), critério de desempate das propostas para empresas que invistam em pesquisa e no desenvolvimento da tecnologia no país (artigo $\left.3^{\circ}, \S 2^{\circ}, I V\right)$ e a possibilidade de estabelecer uma margem de preferência para produtos manufaturados e para serviços nacionais que atendam a normas técnicas brasileiras (artigo $3^{\circ}, \S 5^{\circ}$ ). A referida margem de preferência poderá ser de até $25 \%$ (vinte e cinco por cento) e leva em consideração os seguintes fatores: geração de emprego e renda; efeito na arrecadação de tributos federais, estaduais e municipais; desenvolvimento e inovação tecnológica realizados no País; custo adicional dos produtos e serviços; e em suas revisões, análise retrospectiva de resultados. Tal margem poderá ser estendida aos bens e serviços originários dos Estados Partes do Mercado Comum do Sul- MERCOSUL.

Ademais, foi inserido que, para os produtos manufaturados e serviços nacionais resultantes de desenvolvimento e inovação tecnológica realizados no País, poderá ser estabelecido margem de preferência adicional àquela para produtos manufaturados e para serviços nacionais que atendam a normas técnicas brasileiras (artigo $3^{\circ}, \S 7^{\circ}$ ).

Existe também, entre outras, a Lei n. 10.973/2004 que dispõe sobre incentivos à inovação e à pesquisa científica e tecnológica no ambiente produtivo brasileiro; a Lei n. $8.248 / 1991$, com as alterações principalmente da Lei n. 10.176/2001, que disciplina sobre o processo produtivo básico no setor de informática e automação; a Lei n. 11.196/2005 que prevê um regime especial tributário para a plataforma de exportação de serviços de tecnologia da informação; e a Lei n. 12.715/2012 que versa sobre a desoneração da folha de pagamento de vários setores. ${ }^{47}$

47 Em artigo, Marcia Carla Pereira Ribeiro e Marcelle Franco Espindola Barros 
Em janeiro de 2016, foi sancionada a Lei ${ }^{\circ} 13.243$ que trouxe significativas mudanças, tanto que recebeu a alcunha de Marco Legal da Ciência, Tecnologia e Inovação. Dentre as prescrições normativas, houve profundas modificações e inserções, principalmente, nas Leis $\mathrm{n}^{\circ} 10.973 / 2004,8.666 / 93$, $12.462 / 11$ e $8.958 / 94$. O legislador acrescentou de maneira cristalina "o poder de compra do Estado" ao elevá-lo como princípio (inciso XIII do parágrafo único do artigo $1^{\circ}$ da Lei $\left.\mathrm{n}^{\mathrm{o}} 10.973 / 2004\right)^{48}$, replicando posteriormente no inciso VIII do $\S 2^{\circ}$ do artigo 19 como instrumento de estímulo à inovação nas empresas, quando aplicáveis, e no inciso IX do $\S 6^{\circ}$ do artigo 19 ao estatuir que as iniciativas da União, Estados, Distrito Federal, Municípios, ICTs e suas agências de fomento poderão ser estendidas às ações visando à indução de inovação por meio de compras públicas.

Pertinente às compras governamentais "verdes" (licitações visando à proteção ambiental pelo consumo sustentável) ${ }_{1}^{49}$ no âmbito brasileiro, sem desconhecer a existência de outros atos normativos importantes para o dever de licitações e contratos administrativos sustentáveis (v. g. Lei n. 6.938/1981, Lei n. 12.187/2009 e Lei n. 12.305/2010), a inserção na Lei n. 8.666/93 por meio da Lei n. 12.349/2010 da expressão "promoção do desenvolvimento nacional sustentável", como finalidade da licitação pública no Brasil, foi

explicitam outras várias legislações de incentivo de processo de inovação tecnológica (RIBEIRO, Marcia Carla Pereira; BARROS, Marcelle Franco Espíndola. Contratos de transferência de tecnologia: custos de transação versus desenvolvimento.Revista de Informação Legislativa, Brasília, v. 51, n. 204, p. 43-66 out./dez.2014).

48 XIII - a utilização do poder de compra do Estado para fomento à inovação.

49 Sobre a regulação para o incentivo de condutas que visam à proteção ambiental e práticas de consumo e produção sustentável, vide DROMI, Roberto. La revolución del desarrollo: inovaciones en la gestión pública. Buenos Aires, Madrid, México: Ciudad Argentina - Hispania Libros, 2007, p. 114-118. 
extremamente significativa ${ }^{50}$, bem como a regulamentação no âmbito federal pela Instrução Normativa SLTI/MPOG n. 01, de 19 de janeiro de 2010, e em 2012 pelo Decreto n. 7.746, de 05 de junho que estabeleceu critérios, práticas e diretrizes gerais para a promoção do desenvolvimento nacional sustentável por meio das contratações realizadas pela administração pública federal direta, autárquica, fundacional e pelas empresas estatais dependentes, e para instituir a Comissão Interministerial de Sustentabilidade na Administração Pública - CISAP.

Percebe-se, dessa maneira, que os contratos administrativos ultrapassam as fronteiras de uma mera satisfação imediata dos anseios dos órgãos e entidades da Administração Pública Brasileira, trespassando também a ideia de interesse puramente financeiro para os parceiros e colaboradores do Poder Público a fim de acarretar um direcionamento para a melhor atuação econômica deles. Como se verifica, a regulação estatal via licitações e contratos administrativos já tem acontecido por intermédio de diversos e esparsos textos normativos, mormente no aspecto de fomento (indução) e

50 Convém observar que existiam diversos decretos e regulamentações estaduais que já disciplinavam ou inseriam algumas ferramentas para colimar a sustentabilidade das contratações públicas no Brasil. Por exemplo, Lei do Estado de São Paulo n. 11.878, de 19 de janeiro de 2005, Decreto Estadual do Paraná n. 6.2.52/2006, etc.. Sobre a função social da licitação pública e o desenvolvimento sustentável, vide: FERREIRA, Daniel. Função Social da licitação pública: o desenvolvimento nacional sustentável (no e do Brasil, antes e depois da MP 495/2010). In: Fórum de contratação e gestão pública - FCGP. Belo Horizonte: Fórum, 2010, ano 9, n. 107 nov. p. 49-64 e FERREIRA, Daniel. A licitação pública no Brasil e sua nova finalidade legal: a promoção do desenvolvimento nacional sustentável. Belo Horizonte: Fórum, 2012; BARKI, Teresa Villac Pinheiro; SANTOS, Murillo Giordan (org.) Licitações e contratações públicas sustentáveis. Belo Horizonte: Fórum, 2011; FREITAS, Juarez. Licitações sustentáveis: conceitos e desafios. In: BACELLAR, Romeu Felipe; HACHEM, Daniel Wunder (Coord.). Direito público no MERCOSUL: Intervenção estatal, direitos fundamentais e sustentabilidade. Belo Horizonte: Fórum, 2013, p. 373-385. 
direção de determinadas atividades que sejam de manifesto interesse público. É um caminho incontroverso e que precisa ser muito bem planejado, estruturado normativamente e executado, sob pena de sua completa ineficácia.

Segundo Floriano de Azevedo Marques Neto, a interferência regulatória estatal é imprescindível quando a capacidade dos atores econômicos coloca em risco um valor de natureza coletiva (o meio ambiente, o uso de um bem escasso, um serviço de relevância social) ou for insatisfatória e insuficiente para alcançar um desidério de interesse geral da coletividade (a universalização de um serviço, a acessibilidade de uma comodidade, o incremento da competição, a satisfação dos usuários de um bem essencial, etc..). ${ }^{51}$ Até porque, Chevallier pontua que a atuação estatal na economia não se reduz a uma simples função regulatória, mas sim numa intervenção ativa no jogo econômico, levando em conta o contexto de interdependência ligado ao processo de globalização. ${ }^{52}$

Na mesma linha de encarar a contratação pública como um instrumento com reflexos na macroeconomia, Marçal Justen Filho assevera que as contratações representam meio para "fomentar e assegurar o emprego da mão de obra brasileira e o progresso da indústria nacional, mas preservando o equilíbrio do meio ambiente" ${ }^{53}$

51 MARQUES NETO, Floriano Azevedo. Limites à abrangência e à intensidade da regulação estatal. Revista Eletrônica de Direito Administrativo Econômico, Salvador, Instituto de Direito Público da Bahia, n. 04, nov/dez 2005, jan. 2006. Disponível na internet: http://www.direitodoestado.com. br.> Acesso em 17., jul. 2014, p. 13.

52 CHEVALLIER, Jacques. O Estado Pós-Moderno. Trad. Marçal Justen Filho. Belo Horizonte: Fórum, 2009, p. 73.

53 JUSTEN FILHO, Marçal. Comentários à Lei de Licitações e Contratos Administrativos. 16. ed. São Paulo: RT, 2014, p. 76. 
Desse modo, as licitações e os contratos administrativos são importantes ferramentas de regulação, podendo o Estado utilizar a intervenção na economia por indução ou direção para a proteção dos bens e valores protegidos por sua política regulatória.

\section{$O$ regime diferenciado às microempresas e em- presas de pequeno porte nas licitações e nos con- tratos administrativos: a margem de preferência adicional}

O uso da regulação estatal para fomentar e direcionar as atividades da microempresa e empresa de pequeno porte para que participem de licitações públicas e celebrem contratos administrativos não se justifica tão somente sob o fundamento doutrinário do consenso ou do aspecto financeiro, mas também encontra base na ordem jurídica.

A Constituição da República Federativa do Brasil prescreveu em seu artigo 170 que um dos princípios norteadores da ordem econômica é o tratamento favorecido para as empresas de pequeno porte constituídas sob as leis brasileiras e que tenham sua sede e administração no País. Posteriormente, no mesmo capítulo, enunciou que a União, os Estados, o Distrito Federal e os Municípios dispensarão às microempresas e às empresas de pequeno porte, assim definidas em lei, tratamento jurídico diferenciado, visando a incentivá-las pela simplificação de suas obrigações administrativas, tributárias, previdenciárias e creditícias, ou pela eliminação ou redução destas por meio de lei (artigo 179). ${ }^{54}$

54 "A intervenção estatal na economia, mediante regulamentação e regulação de setores econômicos, faz-se com respeito aos princípios e fundamentos da Ordem Econômica. CF, art. 170." (Supremo Tribunal Federal, RE 422.941, 
Disciplinando tais normas constitucionais, a Lei Complementar $n^{\circ} 123 / 2006^{55}$ atualmente define como microempresa a sociedade empresária, a sociedade simples, a sociedade individual de responsabilidade limitada e o empresário que aufira em cada exercício receita bruta igual ou inferior a $\mathrm{R} \$ 360.000,00$ (trezentos e sessenta mil reais) e como empresa de pequeno porte, igual ou inferior a $\mathrm{R} \$ 4.800 .000,00$ (quatro milhões e oitocentos mil reais). ${ }^{56}$

Salienta-se que a Lei Complementar $n^{0} 123 / 2006$ ao instituir o Estatuto da Microempresa e Empresa de Pequeno Porte tratou de diversas obrigações em diferentes áreas jurídicas, principalmente questões tributárias, mas também preceituou dispositivos atinentes a licitações e contratos, a obrigações civis, previdenciárias e trabalhistas.

Especificamente sobre as licitações e os contratos administrativos, poder-se-ia dividir as suas prescrições, antes de sua alteração pela Lei Complementar n $n^{\circ}$ 147/2014, em

Rel. Min. Carlos Velloso, julgamento em 5-12-2005, Segunda Turma, DJ de 24-3-2006).

55 Artigo $3^{\circ}$, I e II, da Lei Complementar $n^{\circ}$ 123/2006 atualizado pela Lei Complementar $n^{\circ}$ 155/2016.

56 Convém informar que não se deve confundir microempresa e empresa de pequeno porte com empresa optante pelo Simples. O Simples Nacional é um regime tributário que poderá ser adotado pelas MEs e EPPs, mas não lhe é obrigatório. Isto é, a ME e a EPP pode ou não adotar o regime tributário do Simples Nacional, até porque dependendo do caso outros regimes tributários poderão ser mais benéficos. Portanto, o importante para que a ME e EPP possa gozar do regime diferenciado dos artigos 42 a 49 da Lei Complementar n. 123/2006 é que a empresa se enquadre aos valores de faturamentos preconizados no artigo $3^{\circ}$. Para deixar explícito que não se confunde o regime tributário com a caracterização de uma empresa como ME ou EPP para fins licitatórios, houve a inserção do artigo $3^{\circ}$-B na Lei de Licitações: “Art. 3--B. Os dispositivos desta Lei Complementar, com exceção dos dispostos no Capítulo IV, são aplicáveis a todas as microempresas e empresas de pequeno porte, assim definidas pelos incisos I e II do caput e $\S 4^{\circ}$ do art. 3ำ ainda que não enquadradas no regime tributário do Simples Nacional, por vedação ou por opção." 
benefícios e faculdades. Dividia-se em benefícios, porque estes eram diretos e autoaplicáveis desde o momento da publicação da lei, ${ }^{57}$ e as faculdades dependiam de regulamentação e previsão no instrumento convocatório quando possíveis de serem aplicadas. Os primeiros cingiam-se à restrição de regularidade fiscal (artigos 42 e 43) e ao empate ficto (artigo 44), já os segundos (artigo 48) versavam a possibilidade de licitação exclusiva de até $\mathrm{R} \$$ 80.000,00 (oitenta mil reais) para microempresa e empresa de pequeno porte, de subcontratação de até $30 \%$ para microempresa e empresa de pequeno porte quando o contrato não se enquadrasse nestas categorias jurídicas e o parcelamento da licitação para fornecimento de bens e serviços de natureza divisível numa cota de $25 \%$ para participação exclusiva de microempresa e empresa de pequeno porte.

Após a Lei Complementar no 147/2014, o artigo 48 foi substancialmente alterado, além de outros dispositivos, para inserir a licitação exclusiva de até $\mathrm{R} \$ 80.000,00$ (oitenta mil) e a parcela exclusiva de até $25 \%$ em licitações de fornecimento de bens de natureza divisível como deveres-poderes aos agentes públicos em seus certames, ressalvadas as exceções que retratam a sua impossibilidade de uso (artigo 49). Ou

57 “8. Observo, aliás, que os comandos contidos nos arts. 44 e 45 são impositivos ("proceder-se-á da seguinte forma..."), ao passo que a redação conferida aos arts. 47 e 48 deixam claro seu caráter autorizativo ("a administração pública poderá..."). As regras insculpidas nos arts. 44 e 45 não são, portanto, facultativas, mas auto-aplicáveis desde o dia 15.12.2006, data de publicação da Lei Complementar 123." (Tribunal de Contas da União, Acórdão n 2144/2007 - Plenário)

Mesma linha, vide Jair Santana "No que diz respeito especificamente às licitações, as normas consignadas nos artigos 42 a 45 são de eficácia plena e imediata, ou seja, encontram-se produzindo efeitos no mundo jurídico desde a publicação da Lei Complementar n ${ }^{0}$ 123/2006 (DOU, 15. dez.2006)". (SANTANA, Jair e GUIMARÃES, Edgar. Licitações e o novo estatuto da pequena e microempresa: reflexos práticos da $\operatorname{LC} \mathbf{n}^{\circ} 123 / 2006$. Belo Horizonte: Fórum, 2007, p. 22). 
seja, somente deixou como faculdade a factibilidade de subcontratação, sem limite percentual, para microempresa e empresa de pequeno porte quando for contrato de obras e serviços e não celebrado com pequenas empresas (ME e EPP). Em síntese, neste último caso ficou uma faculdade e nos demais um dever obrigacional aos agentes públicos.

Logo após a publicação da Lei Complementar $n^{\circ}$ 123/2006 (15 de dezembro de 2006), alguém poderia objetar a atuação estatal de privilegiar as microempresas e empresas de pequeno porte nas licitações públicas e nos contratos administrativos alegando possível inconstitucionalidade sob o fundamento de violação ao princípio da isonomia. De imediato refuta-se qualquer tentativa de alegar tal inconstitucionalidade, porque, como transcrito anteriormente, a Constituição da República Federativa determinou ao Estado que privilegiasse tais empresas concedendo-lhes vantagens e direcionasse normativamente para tal direção.

Recorrendo ao escólio de Celso Antônio Bandeira de Mello, o tratamento diferenciado somente é legal quando concorrerem três elementos: $1^{\circ}$ ) existência de diferenças nas próprias situações de fato que serão reguladas pelo direito; $2^{\circ}$ ) correspondência (adequação) entre tratamento discriminatório e as diferenças existentes entre as situações de fato; e $3^{\circ}$ ) correspondência (adequação) entre os fins visados pelo tratamento discriminatório e os valores jurídicos consagrados pelo ordenamento jurídico, inclusive com amparo constitucional. ${ }^{58}$ Nesta situação ora comentada, fica patente que os três elementos estão presentes, mormente o amparo constitucional da discriminação positiva a ser efetuada.

Afora a questão da isonomia, pode-se confirmar a constitucionalidade deste regime diferenciado com am-

58 MELLO, Celso Antônio Bandeira de. O conteúdo jurídico do princípio da igualdade. 3. ed. São Paulo: Malheiros, 1999, p. 10. 
paro no princípio constitucional do desenvolvimento do Estado. ${ }^{59}$ Tal norma possui explicitação já no Preâmbulo Constitucional que garante a destinação do ordenamento jurídico para assegurar o exercício dos direitos sociais e individuais, a liberdade, a segurança, o bem-estar, o desenvolvimento, a igualdade e a justiça como valores supremos de uma sociedade fraterna, pluralista e sem preconceitos. $\mathrm{O}$ Preâmbulo possui força integrativa e interpretativa para o restante das normas constitucionais, consonante já decidiu o Supremo Tribunal Federal na ADI ${ }^{\circ} 2.649$ ao enunciar que "referindo-se, expressamente, ao Preâmbulo da Constituição brasileira de 1988, escolia José Afonso da Silva que ‘O Estado Democrático de Direito destina-se a assegurar o exercício de determinados valores supremos. 'Assegurar', tem, no contexto, função de garantia dogmático-constitucional; não, porém, de garantia dos valores abstratamente considerados, mas do seu 'exercício'." 60

59 Não se adentrará à discussão se o desenvolvimento é um princípio explícito ou implícito constitucional. Conforme descreve Luiz Alberto Blanchet, "o fato de um princípio ser apenas implícito e não expresso no texto normativo, não o torna menos importante, têm ambos a mesma importância no sistema que integram." (BLANCHET, Luiz Alberto. Infraestrutura nacional e desenvolvimento sustentável. In: DOTTA, Alexandre Godoy; HACHEM, Daniel Wunder; REIS, Luciano Elias (Org.). Anais do I Seminário ÍtaloBrasileiro em Inovações Regulatórias em Direitos fundamentais, Desenvolvimento e Sustentabilidade e VI Evento de Iniciação Científica da UniBrasil. 1. ed. Curitiba: Negócios Públicos, 2011, p. 26-41, p. 30).

60 Supremo Tribunal Federal, ADI 2.649, voto da Rel. Min. Cármen Lúcia, julgamento em 8-5-2008, Plenário, DJE de 17-10-2008. Na ADI 2.076 que debatia a reprodução ou não do Preâmbulo da Constituição Federativa do Brasil nas Constituições Estaduais, o Supremo Tribunal Federal rechaçou a sua forma normativa, mas na fundamentação do julgado destacou a sua força integrativa e interpretativa: "Preâmbulo da Constituição: não constitui norma central. Invocação da proteção de Deus: não se trata de norma de reprodução obrigatória na Constituição estadual, não tendo força normativa." (ADI 2.076, Rel. Min. Carlos Velloso, julgamento em 15-8-2002, Plenário, DJ de 8-8-2003). 
Além do Preâmbulo, anuvia-se que toda e qualquer interpretação constitucional no Brasil, inclusive para a regulação estatal, deve prezar pelos fundamentos e objetivos fundamentais prescritos na Lei Maior. Neste sentido, a Constituição estabelece em seu artigo $1^{\circ}$ que a cidadania, a dignidade da pessoa humana e os valores sociais do trabalho e da livre iniciativa constituem-se como fundamentos da República Federativa do Brasil, já o artigo $3^{\circ}$ galga como objetivos fundamentais, dentre outros, a garantia do desenvolvimento nacional, a promoção do bem de todos sem qualquer preconceito e a erradicação da pobreza e da marginalização, bem como a redução das desigualdades sociais e regionais. ${ }^{61}$ Novamente aqui se justifica a atuação estatal sob o ponto de vista constitucional da regulação estatal das microempresas e empresas de pequeno porte. ${ }^{62}$

61 O próprio Supremo Tribunal Federal já destacou a necessidade de conceder um tratamento diferenciado às microempresas e empresas de pequeno porte: “O fomento da micro e da pequena empresa foi elevado à condição de princípio constitucional, de modo a orientar todos os entes federados a conferir tratamento favorecido aos empreendedores que contam com menos recursos para fazer frente à concorrência. Por tal motivo, a literalidade da complexa legislação tributária deve ceder à interpretação mais adequada e harmônica com a finalidade de assegurar equivalência de condições para as empresas de menor porte. Risco à autonomia sindical afastado, na medida em que o benefício em exame poderá tanto elevar o número de empresas a patamar superior ao da faixa de isenção quanto fomentar a atividade econômica e o consumo para as empresas de médio ou de grande porte, ao incentivar a regularização de empreendimentos." (Supremo Tribunal Federal, ADI 4.033, Rel. Min. Joaquim Barbosa, julgamento em 15-9-2010, Plenário, DJE de 7-2-2011).

62 Analisando especificamente o princípio do desenvolvimento nacional sustentável, o Supremo Tribunal Federal já proferiu o seguinte julgado: "A questão do desenvolvimento nacional (CF, art. 3", II) e a necessidade de preservação da integridade do meio ambiente (CF, art. 225): O princípio do desenvolvimento sustentável como fator de obtenção do justo equilíbrio entre as exigências da economia e as da ecologia. O princípio do desenvolvimento sustentável, além de impregnado de caráter eminentemente constitucional, encontra suporte legitimador em compromissos internacionais assumidos 
A título ilustrativo, a normatização de benefícios diretos ou indiretos para pequenas empresas não é uma novidade do Brasil. Segundo estudo comparativo da FIESP, em 2010, do Brasil com outros países latino-americanos, constatou-se que: (i) na Argentina havia preferências no âmbito provincial para empresas nacionais e de porte reduzido, bem toda empresa deveria trabalhar associada com empresas de pequeno porte em pelo menos 30\% da obra; (ii) na Colômbia as empresas nacionais de pequeno e médio porte tinham benefícios por meio de linhas de crédito; (iii) na Venezuela havia preferências para bens e serviços produzidos no país para empresas nacionais e para pequenas e médias empresas; e (iv) no Chile e no Peru não havia qualquer vantagem..$^{63}$

Quanto à importância das microempresas e empresas de pequeno porte, segundo Cartilha da Secretaria de Micro e Pequena Empresa da Presidência da República, tem-se os seguintes dados: (i) em 2011, as micro e pequenas empresas representaram $99 \%$ dos estabelecimentos e foram responsáveis por $51,6 \%$ dos empregos privados não agrícolas formais no país e quase $40 \%$ da massa de salários; (ii) entre 2000 e 2011 , de cada $\mathrm{R} \$ 100$ pagos aos trabalhadores no setor privado não agrícola, cerca de $\mathrm{R} \$ 40$, em média, foram pagos por

pelo Estado brasileiro e representa fator de obtenção do justo equilíbrio entre as exigências da economia e as da ecologia, subordinada, no entanto, a invocação desse postulado, quando ocorrente situação de conflito entre valores constitucionais relevantes, a uma condição inafastável, cuja observância não comprometa nem esvazie o conteúdo essencial de um dos mais significativos direitos fundamentais: o direito à preservação do meio ambiente, que traduz bem de uso comum da generalidade das pessoas, a ser resguardado em favor das presentes e futuras gerações." (Supremo Tribunal Federal, ADI 3.540-MC, Rel. Min. Celso de Mello, julgamento em 1-9-2005, Plenário, DJ de 3-2-2006.)

63 Sobre este estímulo à contratação de microempresas e empresas de pequeno porte na América do Sul, vide a obra Segurança jurídica: os aspectos políticos, legais e econômicos no Brasil e na América do Sul. São Paulo: FIESP, 2010, p. 14. 
micro e pequenas empresas; (iii) quanto à sua participação para a formação do Produto Interno Bruto (PIB), estima-se que sua participação gire em torno de $20 \%$ a $27 \%$; (iv) entre os anos de 2000 a 2011, o número de MPE cresceu 50\%, passando de 4,2 milhões para 6,3 milhões; (v) entre 2000 e 2005, foram gerados 2,4 milhões de postos de trabalho nas $\mathrm{MPE}$, isso equivale a um crescimento médio anual de 5,1\% ao ano; (iv) houve um incremento entre os anos de 2005 a 2011, resultando na geração de 4,6 milhões de novos postos de trabalho, o que representa crescimento médio anual de 5,9\% ao ano. ${ }^{64}$ Em síntese, as as microempresas representam uma grande fonte de empregos e zelam pela sobrevivência de diversos pequenos empreendedores e respectivas família. ${ }^{65}$

Além disso, segundo dados extraídos do Caderno de Logística n 04 - "Comprando das Micro e Pequenas Empresas", o Ministério do Planejamento enaltece com dados concretos os avanços ocorridos entre 2007 a 2012 após a implementação do tratamento diferenciado para as microempresas e empresas de pequeno porte na Administração Pública Federal. ${ }^{66}$ Na mesma linha, em 2015 dos itens licitados pelo pregão eletrônico no Comprasnet, $94 \%$ das licitações estavam situada na faixa de até $\mathrm{R} \$ 80 \mathrm{mil}$, em que pese $59 \%$ destas não previram a licitação exclusiva. ${ }^{67}$

64 BRASIL, Secretaria de Micro e Pequena Empresa da Presidência da República. Brasília: 2014, Disponível na internet: http://smpe.gov.br/ assuntos/cartilha tratamentodiferenciado mpe.pdf, Acesso em 18. abril. 2014.

65 CASTRO, Noema Augusta Soares de. Do plano de recuperação judicial para microempresas e empresas de pequeno porte. Revista Brasileira de Estudos Políticos, Belo Horizonte, n. 92, p. 235-272, jul.dez. 2005., p. 238-239.

66 BRASIL, Ministério do Planejamento. Comprando das Micro e Pequenas Empresas (Caderno de Logística n ${ }^{\circ}$ 04). Brasília: 2013, p. 18 e seguintes.

67 NEGÓCIOS PÚBLICOS. Infográficos - Informativo do Instituto Negócios Públicos sobre as Compras Públicas. Curitiba, 2016, p. 32. 
Demonstrada a justificação da relação entre as microempresas e empresas de pequeno porte e a regulação estatal pelas licitações, passa-se a examinar o objeto central deste ensaio que é refletir sobre a margem de preferência adicional inserida no artigo $48, \S 3^{\circ}$, da Lei Complementar $n^{\circ} 123 / 2006$, após a alteração da Lei Complementar n ${ }^{\circ}$ 147/2014, ao preceituar a possibilidade de estipular uma margem de preferência adicional de dez por cento para as microempresas e empresas de pequeno porte sediadas local ou regionalmente.

O parágrafo terceiro do artigo 48 foi prescrito pela Lei Complementar $n^{\circ} 147 / 2014$ e tem a sua hipótese de aplicabilidade especificamente (i) às licitações exclusivas de até $R \$ 80.000,00$ (oitenta mil reais) para microempresa e empresa de pequeno porte, (ii) à possibilidade (faculdade) de subcontratação para microempresa e empresa de pequeno porte quando o contrato de obras e serviços não for celebrado por nenhuma empresa de pequeno porte e (iii) as licitações para fornecimento de bens com natureza divisível com cota de exclusividade de até $25 \%$ para participação exclusiva de microempresa e empresa de pequeno porte. Portanto, o primeiro recorte a ser destacado é que a margem de preferência de até dez por cento para microempresas e empresas de pequeno local ou regional não se aplica a toda e qualquer licitação.

Apesar disso, a mera intelecção do dispositivo legal e do restante da Lei Complementar $n^{\circ} 123 / 2006$ não é suficiente para operacionalizar tal margem de preferência adicional, isto porque ficam algumas dúvidas centrais sobre 1) o que se entende por local ou regional e 2) como procedimentalizar esta margem.

Para disciplinar este e outros assuntos, houve a edição em setembro de 2015 do Decreto Federal n ${ }^{\circ}$ 8.538, ficando previsto no artigo 15 que a sua vigência iniciaria após noven- 
ta dias. O artigo $1^{\circ}$ fixou uma definição de "local" como sendo os limites geográficos do Município onde será executado o objeto da contratação e "regional" os limites geográficos do Estado ou da região metropolitana, que podem envolver mesorregiões ou microrregiões, conforme definido pelo Instituto Brasileiro de Geografia e Estatística - IBGE. Preconizou que esta definição deve ser utilizada como regra, ressalvado quando houver disposição diversa no ato convocatório ou em regulamentação específica no âmbito do órgão ou da entidade promotora da licitação, desde que não desvirtue os objetivos de promover o desenvolvimento econômico e social no âmbito local e regional, ampliar a eficiência das políticas públicas e incentivar a inovação tecnológica.

Em momento ulterior, mais precisamente, no artigo $9^{\circ}$ dispôs que a previsão de margem de preferência adicional de até dez por cento deverá ser justificada e gerará um empate ficto favorável para as microempresas e empresas de pequeno porte locais ou regionais em detrimento das demais empresas, desde que a primeira colocada não pertença à mesma categoria jurídica (ME/EPP local ou regional).

Salienta-se que esta margem de preferência adicional será realizada após todas as etapas anteriores da fase de julgamento das propostas e antes da fase de negociação de valores com o primeiro colocado, isto é, depois da aceitabilidade inicial das propostas, dos lances (se houver, em caso de pregão) e da aceitabilidade final (análise de exeqüibilidade). Ou seja, efetuada a classificação final, far-se-á o exame e a aplicação desta margem de preferência adicional.

Para o Decreto regulamentador, a margem de preferência adicional enseja um "empate ficto", e não propriamente um benefício de preferência, isto porque a ME/EPP local ou regional deverá formular uma nova proposta que seja mais vantajosa do que a que está em primeiro lugar. Caso ela não diminua o seu valor nominalmente, não será consi- 
derada primeira colocada e não passará à fase de habilitação no caso de pregão ou não se sagrará vencedora no caso das modalidades da Lei $n^{0}$ 8.666/93.

Infelizmente, aqui reside a grande ilegalidade do Decreto Federal $n^{\circ} 8.538 / 2015$ ao regulamentar o artigo 48, § $3^{\circ}$, da Lei Complementar $n^{\circ} 123 / 2006$.

O poder regulamentar é a prerrogativa de alguns agentes públicos editarem regulamentos. Entende-se como regulamento, "o (ato) administrativo normativo, editado, mediante decreto, privativamente pelo Chefe do Poder Executivo, segundo uma relação de compatibilidade com a lei para desenvolvê-la." ${ }^{68}$ De acordo com o artigo 84, IV, da Constituição Federal, a expedição de decretos e regulamentos é para a fiel execução das leis, logo os decretos são subalternos às leis e devem tão somente regulamentá-las. Consequentemente, o decreto não pode criar normas ou legislar e muito menos divergir da lei, sob pena de ferir a sua finalidade constitucional.

Odete Medauar elenca algumas justificativas do poder regulamentar, dentre elas que a lei não consegue abrigar todos os pormenores da matéria que disciplina e que só o Poder Executivo possui pleno conhecimento dos mecanismos e meios administrativos indispensáveis à fiel execução da lei, bem como em algumas vezes "é necessária a indicação, adaptação ou criação de órgãos administrativos para o cumprimento da lei; em outras, a execução da lei depende de procedimentos administrativos, da elaboração de formulários, etc.." ${ }^{69}$

68 GASPARINI, Diógenes. Direito Administrativo. 13. ed. São Paulo: Saraiva, 2008, p. 124. Sobre a diferença entre poder regulamentar e poder normativo, vide MOTTA, Fabrício. Função normativa da Administração Pública. Belo Horizonte: Fórum, 2007.

69 MEDAUAR, Odete. Direito Administrativo Moderno. 10. ed., São Paulo: RT, 2006, p.116. 
Com base nesta lição teórica e na delimitação jurídico-objetiva preceituada pela Constituição da República Federativa de 1988 ao poder regulamentar, analisa-se a legalidade do artigo $9^{\circ}$, II, do Decreto Federal n ${ }^{\circ}$ 8.538/2015.

Reiterando o que já foi descrito, a Constituição em seus artigos 170, IV e 179 impõem o dever de conceder um tratamento diferenciado às microempresas e empresas de pequeno porte. Já o artigo $3^{\circ}$ alicerça como objetivos fundamentais da República Federativa do Brasil que seja garantido o desenvolvimento nacional e que se reduza as desigualdades sociais e regionais.

Na mesma direção, o artigo 47 da Lei Complementar $n^{\circ}$ 123/2006 prescreve que nas contratações públicas da administração direta e indireta, autárquica e fundacional, federal, estadual e municipal, deverá ser concedido tratamento diferenciado e simplificado para as microempresas e empresas de pequeno porte objetivando a promoção do desenvolvimento econômico e social no âmbito municipal e regional, a ampliação da eficiência das políticas públicas e o incentivo à inovação tecnológica. Em seu parágrafo único enuncia que enquanto não sobrevier legislação estadual, municipal ou regulamento específico de cada órgão mais favorável à microempresa e empresa de pequeno porte, aplica-se a legislação federal, justamente para evitar que Estados e Municípios diminuíssem o alcance da regulação estatal pretendida.

Como toda a interpretação da legislação deverá ser em conformidade com a Constituição, visualiza-se que inexiste qualquer possibilidade de não prestigiar o âmbito municipal e regional na contratação das microempresas e empresas de pequeno porte. $\mathrm{O}$ próprio Decreto assim descreveu os objetivos da regulamentação, ecoando o artigo 47 da Lei Complementar: promover o desenvolvimento econômico e social no âmbito local e regional, ampliar a eficiência das 
políticas públicas e incentivar a inovação tecnológica. De acordo com os escólios de Cristiana Fortini, a interpretação e aplicação de um "dispositivo sobre a licitação deve traduzir a aplicação de todo o sistema, conferindo-se à regra em discussão, qualquer que seja esta, o significado que mais aprouver à inteireza do sistema." 70

Portanto, a margem de preferência adicional de até dez por cento ${ }^{71}$ deve ser encarada como um benefício direto e autoaplicável às microempresas e empresas de pequeno porte que estejam dentro do percentual estipulado no edital, e não como um direito a empate ficto como nefastamente foi regulamentado. Caso no julgamento da proposta não esteja em primeiro lugar uma ME/EPP local ou regional e haja previsão de margem de preferência adicional, a ME/EPP local ou regional dentro do percentual será classificada em primeiro lugar, ainda que numericamente (financeiramente) não esteja à frente da outra.

Para exemplificar, demonstra-se como deveria ter estatuído o Decreto em um certame após o julgamento das propostas e edital estipulando margem de preferência adicional de $10 \%$ :

70 FORTINI, Cristiana. Licitação: prerrogativas ou privilégios? Anulação, revogação e exceção do contrato não cumprido. In: FORTINI, Cristiana; PEREIRA, Maria Fernanda Pires de Carvalho; CAMARÃO, Tatiana Martins da Costa. Licitações e Contratos: aspectos relevantes. Belo Horizonte: Fórum, 2007, p. 111-118, p. 113.

71 Poderá haver variação no percentual, já que o legislador prescreveu até dez por cento. Da mesma maneira, não se visualiza óbice em estabelecer um percentual para a ME/EPP local e outro percentual para a ME/EPP regional, desde que, por lógica, se prefira o local ao regional. 


\begin{tabular}{|c|c|c|}
\hline $\begin{array}{c}\text { Classificação } \\
\text { após } \\
\text { julgamento }\end{array}$ & Licitante & $\begin{array}{c}\text { Classificacão Final } \\
\text { considerando a margem } \\
\text { de preferência adicional) }\end{array}$ \\
\hline $1^{\circ}$ & $\begin{array}{c}\text { Licitante A (ME) } \\
\mathrm{R} \$ 10.000,00\end{array}$ & $2^{\circ}$ \\
\hline $2^{\circ}$ & $\begin{array}{c}\text { Licitante B (EPP) } \\
\mathrm{R} \$ 10.200,00\end{array}$ & $3^{\circ}$ \\
\hline $3^{\circ}$ & $\begin{array}{c}\text { Licitante C } \\
(\mathrm{ME} \text { local) } \\
\mathrm{R} \$ 10.320,00\end{array}$ & $1^{\circ}$ \\
\hline $4^{\circ}$ & $\begin{array}{c}\text { Licitante D (EPP) } \\
\mathrm{R} \$ 10.480,00\end{array}$ & \multicolumn{2}{|c|}{$4^{\circ}$} \\
\hline
\end{tabular}

Em outras palavras, a microempresa ou a empresa de pequeno porte local ou regional que esteja dentro da margem de preferência goza de um direito de ser classificada em primeiro lugar, ultrapassando os demais na ordem de classificação, ainda que numericamente a sua proposta esteja pior. Como se sabe, a licitação busca a proposta mais vantajosa, o que nem sempre significa a mais barata e menos dispendiosa à Administração Pública. Deve-se fazer um critério de economicidade, e não aritmética financeira. Como dito por Marcus Alcântara, a intenção do legislador foi, além de fomentar a contratação das microempresas e empresas de pequeno porte, incentivar negócios com o comércio local ou regional, o que repercutirá no aspecto socioeconômico. ${ }^{72}$

Regulamentando nesta esteira no sentido de contratar inclusive com preço superior para propalar o mercado local

72 ALCÂNTARA, Marcus. Licitações para microempresas e empresas de pequeno porte. In. TORRES, Ronny Charles L de (Coord.). Licitações Públicas: homenagem ao jurista Jorge Ulisses Jacoby Fernandes. Curitiba: Negócios Públicos, 2016, p. 283-304, p. 301. 
ou regional, atualmente existem normatizações no Estado de Minas Gerais (Decreto Estadual no 46.665/2014 que alterou o Decreto Estadual $\left.n^{\circ} 44.630\right)$ e o Município de São Paulo (Decreto Municipal no 56.475/2015 que permite, desde que não se contrate por preço superior ao praticado no mercado). A partir do momento que o artigo $9^{\circ}$, II, Decreto Federal $\mathrm{n}^{\circ} 8.538$ regulamentou de maneira totalmente conflitante aos objetivos da Constituição da República Federativa de 1988, bem como aos prescritos no artigo 47 da Lei Complementar $\mathrm{n}^{\mathrm{o}} 123 / 2006$ e repetido no artigo $1^{\circ}$ do próprio Decreto, deve-se considerá-lo (o inciso II do artigo $9^{\circ}$ tão somente) como regulamento autônomo, por conseguinte flagrantemente ilegal. O Supremo Tribunal Federal tem posicionamento de que o decreto que usurpa da sua função regulamentar e seja autônomo constitui-se em uma ilegalidade, e não inconstitucionalidade. ${ }^{73}$ No mesmo diapasão, Fabrício Motta

73 DIREITO CONSTITUCIONAL E ADMINISTRATIVO. AÇÃO DIRETA DE INCONSTITUCIONALIDADE: ATO NORMATIVO. DECRETO FEDERAL No 1990, DE 29.08.1996: ATO ADMINISTRATIVO. IMPOSSIBILIDADE JURÍDICA DA AÇÃO. 1. A Lei no 8.031, de 12.04.1990, criou o Programa Nacional de Desestatização e deu outras providências. 2. E o Decreto $n^{\circ}$ 1.990, de 29.08.1996, baixado pela Presidência da República, "no uso da atribuição que lhe confere o artigo 84, inciso IV, da Constituição e tendo em vista o disposto" naquela Lei, visou a executá-la. 3. Trata-se, pois, de ato administrativo de mera execução da Lei. Não propriamente normativo. Insuscetível, assim, de controle concentrado de constitucionalidade, "in abstrato", mediante Ação Direta de Inconstitucionalidade perante o Supremo Tribunal Federal, pois esta só é admitida pela C.F., quando impugna "ato normativo" (art. 102, I, “a”). 4. Se o Decreto, eventualmente, tiver excedido os limites da Lei $\mathrm{n}^{\mathrm{o}}$ 8.031, de 12.04.1990, ou mesmo do Decreto $\mathrm{n}^{\mathrm{o}} 1.204$, de 29.07.1994, que a regulamentou, conforme se alegou na inicial, então poderá ser acoimado de ilegal, nas instâncias próprias, que realizam o controle difuso, "in concreto", de legalidade dos atos administrativos. 5. Aliás, o próprio controle jurisdicional de constitucionalidade de ato meramente administrativo, de execução de lei, pode, igualmente, ser feito nas instâncias ordinárias do Poder Judiciário. Não, assim, diretamente perante esta Corte. 6 . Tudo conforme precedentes referidos nas informações. 7. A.D.I. não conhecida, prejudicado o requerimento de medida cautelar. 
esclarece que a jurisprudência do Supremo Tribunal Federal consolidou-se para inadmitir a possibilidade de controle de constitucionalidade por via de ação nas situações em que os atos normativos ostentarem caráter auxiliar ou secundário, como no caso dos decretos regulamentares, até porque "nesses casos, ainda de acordo com o STF, o extravasamento dos limites impostos pela lei caracterizará ilegalidade, e não inconstitucionalidade apreciável mediante controle concentrado. O controle direto é admissível, contudo, quando o ato normativo supre a lei onde a Constituição a exige, invadindo o campo da reserva legal." 74

Dessa feita, verifica-se que a regulamentação do artigo $9^{\circ}$, inciso II, do Decreto Federal no 8.538/2015 está em total descompasso ao caráter desenvolvimentista da política regulatória das microempresas e empresas de pequeno porte por intermédio das licitações e dos contratos, já que obstaculiza o desenvolvimento nacional e a diminuição das desigualdades regionais e locais ao mutilar o direito de preferência da microempresas e empresas de pequeno porte locais e regionais a um critério de empate ficto. Via de consequência, está negando aplicabilidade às opções do legislador quando redigiu os artigos 47 e 48 da Lei Complementar $n^{\circ} 123 / 2006$, após atualização pela Lei Complementar nº 147/2014, e descumprindo de forma frontal diversas normas constitucionais extraídas dos artigos $1^{\circ}, 3^{\circ}, 170$ e 179.

(Supremo Tribunal Federal, ADI 1544, Relator(a): Min. SYDNEY SANCHES, Tribunal Pleno, julgado em 25/06/1997, DJ 05-09-1997 PP-41869 EMENT VOL-01881-01 PP-00001)

74 MOTTA, Fabrício. Função normativa da Administração Pública. Belo Horizonte: Fórum, 2007, p. 240. 


\section{Conclusão}

Percebe-se claramente que a regulação estatal pela via das licitações públicas e dos contratos administrativos, focando as microempresas e empresas de pequeno porte é um instrumento importante e guarda plena compatibilidade nos objetivos fundamentais e na ordem econômica da República Federativa do Brasil, por isso tal regulação é legítima e está fundada na Constituição. ${ }^{75}$

Assim sendo, a intervenção estatal pelo incentivo e pela direção normativa deverá continuar sendo diretriz para a política regulatória brasileira, inclusive com base nos dados econômicos trazidos ao longo deste ensaio, que justificam a sua continuidade visando ao desenvolvimento do Estado Brasileiro.

Por fim, compreende-se que a margem de preferência adicional para as microempresas e empresas de pequeno porte locais ou regionais representa um grande avanço para propiciar a diminuição das desigualdades regionais e locais, todavia infelizmente a regulamentação do artigo $9^{\circ}$, inciso II, do Decreto Federal no 8.538/ 2015 deturpou a sua finalidade ao prescrever uma regra normativa em total descompasso ao caráter desenvolvimentista, afrontando tanto a Constituição quanto a Lei Complementar no 123/2006.

75 “Se a Administração encontrar a habilitação do seu agir ou a regulação da sua conduta em normas da Constituição que, sem qualquer mediação legislativa lhe são diretamente dirigidas, diz-se que estamos diante de uma Administração fundada na Constituição." (OTERO, Paulo. Manual de Direito Administrativo. Coimbra: Almedina, 2013, p. 203). 


\section{Referências Bibliográficas}

ALCÂNTARA, Marcus. Licitações para microempresas e empresas de pequeno porte. In. TORRES, Ronny Charles L de (Coord.). Licitações Públicas: homenagem ao jurista Jorge Ulisses Jacoby Fernandes. Curitiba: Negócios Públicos, 2016, p. 283-304.

ALMEIDA, Fernando Dias Menezes. Contrato administrativo. São Paulo: QuartierLatin, 2012.

BARKI, Teresa Villac Pinheiro; SANTOS, Murillo Giordan (org.) Licitações e contratações públicas sustentáveis. Belo Horizonte: Fórum, 2011.

BLANCHET, Luiz Alberto. Curso de Direito Administrativo. 5. ed. Curitiba: Juruá, 2007.

. Infraestrutura nacional e desenvolvimento sustentável. In: DOTTA, Alexandre Godoy; HACHEM, Daniel Wunder; REIS, Luciano Elias (Org.). Anais do I Seminário Ítalo-Brasileiro em Inovações Regulatórias em Direitos fundamentais, Desenvolvimento e Sustentabilidade e VI Evento de Iniciação Científica da UniBrasil. 1. ed. Curitiba: Negócios Públicos, 2011, p. 26-41.

BRASIL, Ministério do Meio Ambiente. Licitação sustentável. Disponível em: <http://www.mma.gov.br/ responsabilidade-socioambiental/a3p/eixos-tematicos/ item/526\&gt>. Acesso em: 30 de mar. de 2015.

BRASIL, Secretaria de Micro e Pequena Empresa da Presidência da República. Brasília: 2014, Disponível na internet: http://smpe.gov.br/assuntos/cartilha_tratamentodiferenciado_mpe.pdf, Acesso em 18. abril. 2016.

BRASIL, Ministério do Planejamento. Comprando das 
Micro e Pequenas Empresas (Caderno de Logística n ${ }^{\circ}$ 04). Brasília: 2013.

CALDAS, Roberto Correia da Silva Gomes; MARTINS, Thiago Penido. Princípios do Equador e Governança Regulatória nas contratações públicas sustentáveis: implicações nas desapropriações. Revista Brasileira de Estudos Políticos, Belo Horizonte, n. 112, p. 183-229, jan.jun. 2016.

CASTRO, Noema Augusta Soares de. Do plano de recuperação judicial para microempresas e empresas de pequeno porte. Revista Brasileira de Estudos Políticos, Belo Horizonte, n. 92, p. 235-272, jul.dez. 2005.

CARNELUTTI, Francesco. Metodologia do Direito. Trad. Dr. Frederico Paschoal. 3. ed. Campinas: Bookseller, 2005.

CARRIÓ, Genaro. Notas sobre Derecho y Lenguaje. 4. ed. Buenos Aires: Abeledo-Perrot, 1973.

CHEVALLIER, Jacques. O Estado Pós-Moderno. Trad. Marçal Justen Filho. Belo Horizonte: Fórum, 2009.

COELHO, Saulo de Oliveira Pinto; ASSIS, Aline Neves de. Um constitucionalismo do espetáculo? Espetacularização das políticas públicas e ineficiência do controle jurídico-constitucional. Revista Brasileira de Estudos Políticos, Belo Horizonte, n. 115, p. 541-584, jul.dez. 2017.

DROMI, Roberto. Derecho Administrativo. 10. ed. Buenos Aires: Ciudad Argentina, 2004.

La revolución del desarrollo: inovaciones en la gestión pública. Buenos Aires, Madrid, México: Ciudad Argentina - Hispania Libros, 2007.

FALCÃO, Maurin Almeida. O Estado, o mercado e as transformações econômicas, políticas e sociais como determinantes de uma economia política do tributo. Revista 
Brasileira de Estudos Políticos, Belo Horizonte, n. 104, p. 263-289, jan.jun. 2012.

FERRAZ, Luciano. Função regulatória da licitação. Revista Eletrônica de Direito Administrativo Econômico, Salvador, Instituto de Direito Público da Bahia, n. 19, ago.set.out., 2009. Disponível na internet: http:/ / www.direitodoestado.com. br.> Acesso em 12. jul. 2014.

FERREIRA, Daniel. A licitação pública no Brasil e sua nova finalidade legal: a promoção do desenvolvimento nacional sustentável. Belo Horizonte: Fórum, 2012.

. Função Social da licitação pública: o desenvolvimento nacional sustentável (no e do Brasil, antes e depois da MP 495/2010). In: Fórum de contratação e gestão pública - FCGP. Belo Horizonte: Fórum, 2010, ano 9, n. 107 nov. p. 49-64.

FIESP. Segurança jurídica: os aspectos políticos, legais e econômicos no Brasil e na América do Sul. São Paulo: FIESP, 2010, p. 14.

FORTINI, Cristiana. Contratos administrativos: franquia, concessão, permissão e PPP. 2. Ed. São Paulo: Atlas, 2009. Licitação: prerrogativas ou privilégios? Anulação, revogação e exceção do contrato não cumprido. In: FORTINI, Cristiana; PEREIRA, Maria Fernanda Pires de Carvalho; CAMARÃO, Tatiana Martins da Costa. Licitações e Contratos: aspectos relevantes. Belo Horizonte: Fórum, 2007, p. 111-118, p. 113.

FREITAS, Juarez. Licitações sustentáveis: conceitos e desafios. In: BACELLAR, Romeu Felipe; HACHEM, Daniel Wunder (Coord.). Direito público no MERCOSUL: Intervenção estatal, direitos fundamentais e sustentabilidade. 
Belo Horizonte: Fórum, 2013.

GASPARINI, Diógenes. Direito Administrativo. 13. ed. São Paulo: Saraiva, 2008.

GONÇALVES, Pedro Antonio Pimenta da. Entidades privadas com poderes públicos: o exercício de poderes públicos de autoridade por entidades privadas com funções administrativas. Coimbra: Edições Almedina, 2008.

Reflexões sobre o Estado Regulador e o Estado Contratante. Coimbra: Coimbra Editora, 2013.

GRAU, Eros Roberto. A ordem econômica na Constituição de 1988. 15. Ed. São Paulo: Malheiros, 2012.

JUSTEN FILHO, Marçal. Comentários à Lei de Licitações e Contratos Administrativos. 16. ed. São Paulo: RT, 2014 Curso de direito administrativo. 8. Ed. Belo Horizonte: Fórum, 2012.

LARENZ, Karl. Metodologia da Ciência do Direito. Fundação Calouste Gulbenkian.

MARQUES NETO, Floriano Azevedo. Limites à abrangência e à intensidade da regulação estatal. Revista Eletrônica de Direito Administrativo Econômico, Salvador, Instituto de Direito Público da Bahia, n. 04, nov/dez 2005, jan. 2006. Disponível na internet: http:/ / www.direitodoestado.com. br.> Acesso em 17., jul. 2014.

MEDAUAR, Odete. Direito administrativo em evolução. 2. ed. São Paulo: Revista dos Tribunais, 2003.

MEDAUAR, Odete. Direito Administrativo Moderno. 10. ed., São Paulo: RT, 2006.

MELLO, Célia Cunha. O fomento da Administração Pública. Belo Horizonte: Del Rey, 2003. 
MELLO, Celso Antônio Bandeira de. Curso de Direito Administrativo. 25. ed. São Paulo: Malheiros, 2008.

. O conteúdo jurídico do princípio da igualdade. 3. ed. São Paulo: Malheiros, 1999.

MONCADA, Luís S. Cabral de. 6. ed. Direito Económico. Lisboa: Coimbra Editora, 2012.

MOREIRA NETO, Diogo Figueiredo. A regulação sob a perspectiva da nova hermenêutica. Revista Eletrônica de Direito Administrativo Econômico (REDAE), Salvador, Instituto Brasileiro de Direito Público, $\mathrm{n}^{0}$ 12, novembro/ dezembro/janeiro, 2008. Disponível na internet: http:// www.direitodoestado.com.br.> Acesso em 30, abril. 2016.

. Mutações do Direito Administrativo. 3. ed. Rio de Janeiro: Renovar, 2007.

MOREIRA, Egon Bockmann. O Direito Administrativo Contemporâneo e Intervenção do Estado na Ordem Econômica. Revista Eletrônica de Direito Administrativo Econômico, Salvador, Instituto de Direito Público da Bahia, $\mathrm{n}^{\mathrm{o}}$ 01, fevereiro,2005. Disponível na internet: http:/ / www. direitodoestado.com.br.> Acesso em 29. abril. 2016.

MOTTA, Fabrício. Função normativa da Administração Pública. Belo Horizonte: Fórum, 2007.

MOTTA, Paulo Roberto Ferreira. Regulação e universalização dos serviços públicos. Belo Horizonte: Fórum, 2009.

Regulação e universalização dos serviços públicos. Belo Horizonte: Fórum, 2009.

NEGÓCIOS PÚBLICOS. Infográficos - Informativo do Instituto Negócios Públicos sobre as Compras Públicas. Curitiba, 2016. 
OLIVEIRA, Gustavo Justino de. A arbitragem e as parcerias públicos-privadas. In. SUNDFELD, Carlos Ari. (Org) Parcerias Público-Privadas. São Paulo: Malheiros, 2005.

OLIVEIRA, José Roberto Pimenta. Os princípios da razoabilidade e da proporcionalidade no Direito Administrativo Brasileiro. São Paulo: Malheiros, 2006, p. 514-515).

ORTIZ, Gaspar Ariño. Sucessos e Fracassos da Regulação. Revista Eletrônica de Direito Administrativo Econômico, Salvador, Instituto de Direito Público da Bahia, no. 3, ago-set-out, 2005. Disponível na Internet: <http://www. direitodoestado.com.br>. Acesso em: 20 de abril de 2016.

OTERO, Paulo. Manual de Direito Administrativo. Coimbra: Almedina, 2013.

PUIGPELAT, Oriol Mir. Globalización, Estado y Derecho. Las transformaciones del Derecho Administrativo. Madrid: Civitas Ediciones, 2004.

RIBEIRO, Marcia Carla Pereira; BARROS, Marcelle Franco Espíndola. Contratos de transferência de tecnologia: custos de transação versus desenvolvimento.Revista de Informação Legislativa, Brasília, v. 51, n. 204, p. 43-66 out./ dez.2014.

ROCHA, Silvio Luis Ferreira da. Terceiro Setor. 2. ed. São Paulo: Malheiros, 2006.

SANTANA, Jair e GUIMARÃES, Edgar. Licitações e o novo estatuto da pequena e microempresa: reflexos práticos da LC $\mathbf{n}^{0}$ 123/2006. Belo Horizonte: Fórum, 2007.

SILVA, Almiro do Couto e. Notas sobre o conceito de ato administrativo. In: SOUTO, Marcos Juruena Villela e OSÓRIO, Fábio Medina (Coords.). Direito administrativo - Estudos em homenagem a Diogo Figueiredo Moreira Neto. Rio de Janeiro: Lumen Juris, 2006, p. 271-292. 
VALLE, Vivian Lima López. Serviço público, desenvolvimento econômico e a nova contratualização da Administração Pública: o desafio na satisfação dos direitos fundamentais. In: BACELLAR FILHO, Romeu Felipe; GABARDO, Emerson; HACHEM, Daniel Wunder (Coord.). Globalização, Direitos Fundamentais e Direito Administrativo: novas perspectivas para o desenvolvimento econômico e socioambiental. Belo Horizonte: Fórum, 2011, p. 273-284.

VILLANUEVA, Luis F. Aguiar. Gobernanza y gestión pública. México: FCE, 2006.

Recebido em 10/04/2017.

Aprovado em 13/06/2017.

\section{Luciano Elias Reis}

E-mail: luciano@rcl.adv.br

\section{Luiz Alberto Blanchet}

E-mail: blanchet@blanchet.adv.br 